\title{
SPECTRUM OF HIDROCYSTOMAS: A CASE REPORT
}

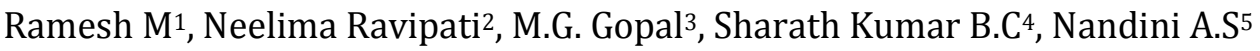

\section{HOW TO CITE THIS ARTICLE:}

Ramesh M, Neelima Ravipati, MG Gopal, Sharath Kumar BC, Nandini AS. "Spectrum of hidrocystomas: a case report". Journal of Evolution of Medical and Dental Sciences 2013; Vol2, Issue 49, December 09; Page: 9534-9538.

ABSTRACT: Hidrocystomas are rare cystic lesions that form benign tumors of the sweat glands. In this report we present two classical cases of apocrine and eccrine hidrocystomas and review the epidemiological, histological and clinical features. The effectiveness of experimental treatment methods and present information about associated syndromes and differential diagnosis have also been discussed.

KEY WORDS: Hidrocystomas, apocrine and eccrine hidrocystomas.

INTRODUCTION: Apocrine hidrocystoma is a lesion produced by cystic dilatation of apocrine glands, usually presents as a solitary lesion around the eye. Eccrine hidrocystoma is a tumor produced by mature, deformed eccrine sweat units, whose secretions dilate the ducts, usually situated on the face and are often multiple.

CASE PRESENTATION: A 24 year old patient presented with a single, small, clear, cystic papule filled with clear fluid. It had been present since several months. The lesion was observed on the lateral aspect of the left upper eyelid and measured approximately $3 \mathrm{~mm} \times 3 \mathrm{~mm}$. The patient denied any diplopia, vision loss, or any other lesions on the body. His review of systems, personal and family histories were all normal and non contributory. Treatment options were discussed with the patient. A 34 year old housewife presented with multiple, small, translucent cystic papules which were filled with watery fluid. Lesions were present since 3years and are asymptomatic. Patient gives history of exacerbation of lesions in summer. On local examination the lesions were observed on the lower eyelids, malar area and on forehead. A clinical diagnosis of hidrocystoma was given. On histopathological examination there is well demarcated unilocular cyst lined by double layer of cuboidal cells which suggests eccrine hidrocystoma.

\section{DISCUSSION:}

\begin{tabular}{|c|c|}
\hline APOCRINE HIDROCYSTOMAS & ECCRINE HIDROCYSTOMAS \\
\hline 1. Primarily solitary & 1. Solitary or multiple \\
\hline 2. Ranges from dark-blue tint to black. & 2. Ranges from flesh-colored to light blue tint \\
\hline 3. $3-15 \mathrm{~mm}$ in diameter & 3. $1-6 \mathrm{~mm}$ in diameter \\
\hline 4. $30-75$ years & 4. 30-75years \\
\hline $\begin{array}{l}\text { 5. Females and males affected in equal } \\
\text { numbers. }\end{array}$ & 5. More prevalent among females than males \\
\hline $\begin{array}{l}\text { 6. Single/double cuboidal-columnar } \\
\text { epithelium }\end{array}$ & 6. Lined by 1-2 layers of cuboidal epithelium \\
\hline 7. $S-100$ negative, $\mathrm{PAS}$ positive & 7. $S-100$ positive, $\mathrm{PAS}$ negative \\
\hline $\begin{array}{l}\text { 8. Decapitation of secretory cells, } \\
\text { papillary projections seen. }\end{array}$ & 8. No decapitation of cells, no secretory cells \\
\hline 9. Face, ears, head, chest, shoulders & 9.Malar, periorbital, chest, axilla, neck \\
\hline
\end{tabular}


Although rare and typically asymptomatic, eccrine and apocrine hidrocystomas are often interest of physicians of different specialities. When encountered by practitioners the approach to these lesions is facilitated by clinical recognition of different subtypes and knowledge about their management. Furthermore, their close resemblance to certain, more serious skin disorders such as basal cell carcinomas necessitates and understanding histology of each type of hidrocystoma for purpose of differential diagnosis. Hence in this brief review we present a simplified approach to the diagnosis and management of both types of hidrocystomas.

Epidemiology: Apocrine hidrocystomas affect the same group as do eccrine hidrocystomas, and rarely occur during childhood and adolescence. They can appear as single or multiple cystic lesions.

Eccrine hidrocystomas are relevant in adults between 30 to 70 years of age. Solitary eccrine hidrocystomas are equally prevalent among males and females; however, multiple eccrine hidrocystomas are mainly seen in female patients.

Clinical presentation: Apocrine hidrocystomas presents as dome-shaped, solitary, clear, cystic nodules with a smooth surface, and the color varies, ranging from flesh -colored to blue-black. They can be presented as either solitary or multiple lesions. But multiple lesional presentation is rare. The cyst tend to stay asymptomatic and will follow a gradual course until a certain size is reached. There is no evidence of seasonal variations, whereas patients tend to present with eccrine hidrocystomas mostly during hot, humid weather.

Eccrine hidrocystomas are benign tumors of sweat gland origin and are classified into 2 major groups: the smith type, which is the most prevalent solitary type, and the Robinson or multiple type. They are typically dome-shaped, have an amber, brown, or bluish tint and range from $1-6 \mathrm{~mm}$ in diameter. During hot or humid weather, these lesions will grow in size and/ or multiply in number.

Histology and pathogenesis: Apocrine hidrocystomas appear as unilocular or multilocular under the microscope. The cyst wall is composed of an inner layer of secretory columnar epithelium. The epithelium is either a single or double layer of cuboidal-columnar epithelium, which lies above an outer myoepithelial cell layer. PAS- positive granules are observed in the presence of lipofuscin granules. Apocrine hidrocystomas also encompass papillary projections, which are not usually seen in the eccrine hidrocystomas. These projections are vascular connective tissue, covered by the secretory epithelium. Papillary projections then appear on the lumen of the cysts as an outgrowth extension from the wall of the cyst.

Eccrine hidrocystomas usually result from dilation of cystic excretory eccrine glands due to retention of sweat and dilation or blockage of the sweat duct. Under the microscope, eccrine hidrocystomas appear as unilocular cysts, which usually contain a single cystic cavity composed of 1 or 2 layers of cuboidal cells. They are located within the mid-dermal to superficial layers of the skin, especially around the eyes. Unlike their apocrine counterpart, there are no secretory cells seen and decapitation of cells is not viewed under the microscope. Histochemically, they stain positive for S100 protein (solitary type), whereas apocrine hidrocystomas do not. The cyst and epidermis do not communicate, and the periodic acid-Schiff (PAS)-positive granules are not observed. 
Associated syndromes: The inherited disorders that are most commonly associated with the presence of multiple eccrine/apocrine hidrocystomas are Goltz-Gorlin syndrome and Schopf-SchulzPassarge syndrome.

Goltz-Gorlin (also known as Jessner-Cole syndrome, or focal dermal hypoplasia) tends to occur sporadically, with few familial cases having X-linked dominant transmission; it occurs mostly in females. Its cardinal features are microcephaly; midfacial hypoplasia; malformed ears; microphthalmia; periocular multiple hidrocystomas; papillomas of the lip, tongue, anus, and axilla; skeleton abnormalities; and mental retardation.

Schopf-Schulz-Passarge is an autosomal recessive syndrome characterized by multiple eyelid apocrine hidrocystoma, palmoplantar hyperkeratosis, hypodontia, and hypotrichosis. It is further characterized by hypotrichosis, cysts of the eyelids, and multiple periocular apocrine hidrocystomas.

Graves' disease has also been associated with multiple eccrine hidrocystomas, possibly due to hyperhidrosis, which is seen in hyperthyroid patients. This is further supported by the disappearance of lesions after treatment of hyperthyroidism.

Differential diagnosis: Eccrine hidrocystomas and apocrine hidrocystomas have a very similar presentation, and their distinction from other head and neck cyst-like lesions must ultimately be verified on biopsy and by careful examination under the microscope. For both types, cystic lesions such as epidermal inclusion cysts, mucoid cysts, hemangioma, and lymphangioma are considered in the differential. Attention is given to cysts (mostly apocrine hidrocystomas) that resemble basal cell carcinoma of the eyelid or malignant melanoma because of their color (typically blue-black). A biopsy of the lesions is very important to exclude these diseases

Management: The most common approach to the treatment of hidrocystomas (eccrine and apocrine) is simple needle puncture. However, in the Robinson type, a simple needle puncture will not produce lasting improvement. Multiple-type lesions have been successfully treated with topical $1 \%$ atropine or scopolamine creams, although anticholinergic side effects could cause patients to discontinue the treatment.Excision of hidrocystomas can lead to scars, and treatment involving incisions and drainage can lead to recurrence after 6 weeks; this can be overcome by cauterization and electrodessication of the cyst wall.

Gupta and colleagues reported the use of electrodessication to be successful in the treatment of multiple apocrine tumors of less than $1 \mathrm{~cm}$ in diameter. Other methods that have shown success have been carbon dioxide laser vaporization and laser treatment. Tanzi and colleagues effectively treated a patient with pulsed-dye treatment with a 585-nm laser, and no recurrence was observed after 18 months of treatment. Finally, avoiding hot temperatures or humid conditions will help prevent worsening of symptoms in patients diagnosed with eccrine-type hidrocystomas.

CONCLUSION: Hidrocystomas are benign cystic lesions that typically occur in the facial region. Eccrine and apocrine hidrocystomas comprise the 2 main groups. Their clinical diagnosis requires knowledge of their differentiating characteristics in order to rule out other benign cystic lesions, and a biopsy must be obtained for histologic study. Management of hidrocystomas mainly involves simple needle puncture; however, other treatments such as electrodessication, anticholinergic 
creams, carbon dioxide vaporization, and laser treatment have all shown success in treating different types of hidrocystomas.

\section{REFERENCES:}

1. Alfadley A, Al Aboud K, Tulba A, Mazen M. Multiple eccrine hidrocystomas of the face.Int J Dermatol. 2001;40:125-129.

2. Alagheband M, Maida MF. Asymptomatic periorbital, bluish cystic papule. Cortlandt Forum. 2004;17:36-41.

3. Kaur C, Sarkar R, Kanwar AJ, Mohan H. Multiple eccrine hidrocystomas. J Eur Acad Dermatol Venereol. 2002;16:288-290.

4. Gupta S, Handa U, Handa S, Mohan H. The efficacy of electrosurgery and excision in treating patients with multiple apocrine hidrocystomas. Dermatol Surg. 2001;27:382-384.

5. del Pozo J, García-Silva J, Peña-Penabad C, Fonseca E. Multiple apocrine hidrocystomas: treatment with carbon dioxide laser vaporization. J Dermatolog Treat.2001;12:97-100.

6. Blugerman G, Schavelzon D, D'Angelo S. Multiple eccrine hidrocystomas: a new therapeutic option with botulinum toxin. Dermatol Surg. 2003;29:557-559.

7. Ascherman JA, Knowles SL, Troutman KC. Extensive facial clefting in a patient with Goltz syndrome: multidisciplinary treatment of a previously unreported association. Cleft Palate Craniofac J. 2002;39:469-473.

8. Gira AK, Robertson D, Swerlick RA. Multiple eyelid cysts with palmoplantar hyperkeratosisquiz case. Arch Dermatol. 2004;140:231-236.

9. Kim YD, Lee EJ, Song MH, Suhr KB, Lee JH, Park JK. Multiple eccrine hidrocystomas associated with Graves' disease. Int J Dermatol. 2002;41:295-297.

10. Tanzi E, Alster T. Pulsed dye laser treatment of multiple eccrine hidrocystomas: a novel approach. Dermatol Surg. 2001;27:898-900.

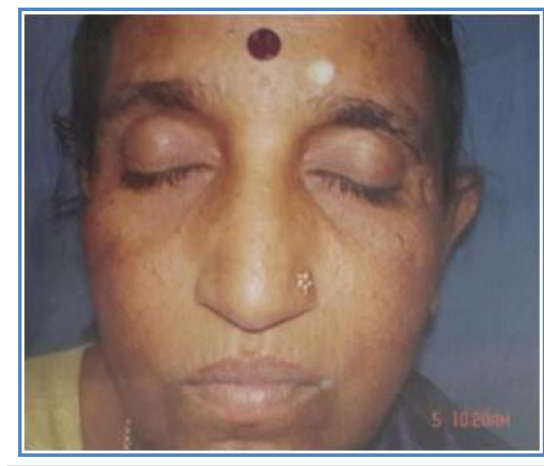

FIG. 1: Multiple shinny papulo vesicular Lesions on the face

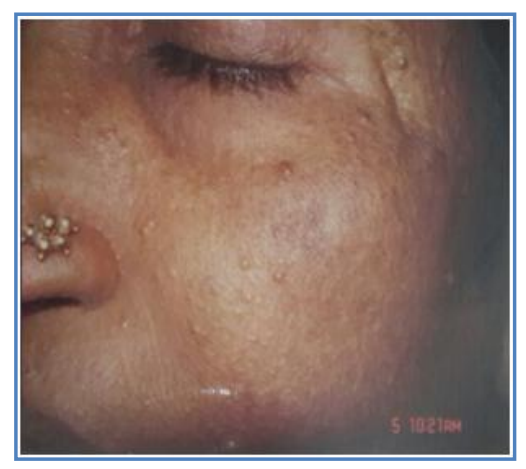

FIG. 2: Close up view showing Translucent vesicular lesions 


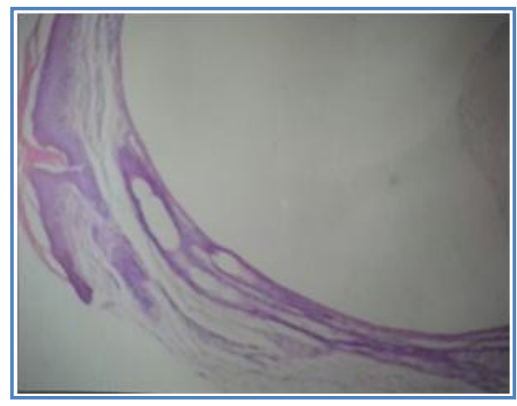

FIG.3: Histopathology showing well demarcated unilocular cyst Lined by double layer of cuboidal cells
FIG. 4: Single, pinkish, cystic lesion near the left upper eyelid

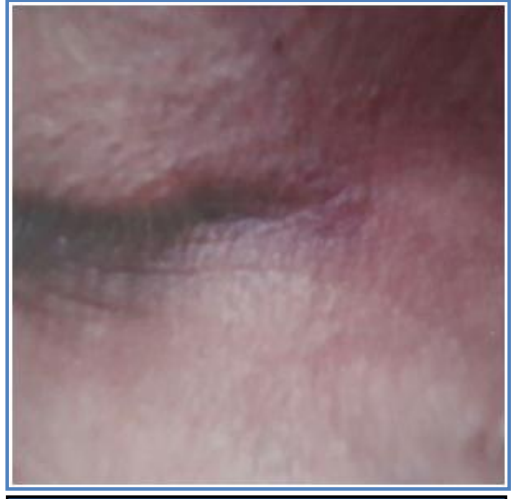

FIG. 5: Complete resolution After puncturing of lesion

\section{AUTHORS:}

1. Ramesh M.

2. Neelima Ravipati

3. M.G. Gopal

4. Sharath Kumar B.C.

5. Nandini A.S.

\section{PARTICULARS OF CONTRIBUTORS:}

1. Associate Professor, Department of Dermatology, Kempegowda Institute of Medical Sciences.

2. Post Graduate Student, Department of Dermatology, Kempegowda Institute of Medical Sciences.

3. Professor and HOD, Department of Dermatology, Kempegowda Institute of Medical Sciences.
4. Professor, Department of Dermatology, Kempegowda Institute of Medical Sciences.

5. Assistant Professor, Department of Dermatology, Kempegowda Institute of Medical Sciences.

\section{NAME ADRRESS EMAIL ID OF THE CORRESPONDING AUTHOR:}

Dr. Neelima Ravipati, $330 \mathrm{y}, 1^{\text {st }}$ Cross, $7^{\text {th }}$ Main, $4^{\text {th }}$ Block, Banshankari $3^{\text {rd }}$ Stage,

Bangalore - 85.

Email - dr.neelimaravipati@gmail.com

Date of Submission: 18/11/2013.

Date of Peer Review: 19/11/2013.

Date of Acceptance: 30/11/2013.

Date of Publishing: 03/12/2013 